\title{
Konsumsi karbohidrat dan lemak dan hubungannya dengan daya tahan jantung paru atlet sepak bola PS Semen Padang Divisi Utama PSSI Liga Bank Mandiri IX tahun 2003
}

\author{
Ferry $^{1}$, Woro Kushartanti², M. Noerhadi
}

\begin{abstract}
Background: Football is body movement that need energy balanced for maintaining optimum cardiorespiratory endurance. Macronutrient and micronutrient are the most nutrient needed to produce energy so that athletes have maximal performance in each sport activity. Athlete's menu must be consist of $60-70 \%$ carbohydrate and $20-25 \%$ fat of total energy.

Objective: To find out the correlation between the pattern of carbohydrate and fat intake with cardiorespiratory endurance of football athletes of PS Semen Padang in the top division of PSSI Liga Bank Mandiri in 2003.

Method: This research was observational with cross sectional design. The subjects were football athletes of PS Semen Padang in the top division of PSSI Liga Bank Mandiri in 2003. Variables consisted of the pattern of carbohydrate and fat intake, and cardiorespiratory endurance. Data were analysed using univariate, bivariate, and multivariate analysis.

Results: There were no significant correlation between carbohydrate $(p=0.751)$ and fat $(p=0.297)$ intake with cardiorespiratory endurance, while BMI $(p=0.034)$, triglyceride $(p=0.044)$ and body fat $(p=0.007)$ had significant correlation with cardiorspiratory endurance. The most influential variable to cardiorespiratory endurance was body fat $(O R=12.00)$. Conclusion: There were significant correlation between BMI, triglyceride, and body fat with cardiorespiratory endurance of football athletes of PS Semen Padang in the top division of PSSI Liga Bank Mandiri in 2003, but there was no correlation between pattern of carbohydrate and fat intake with cardiorespiratory endurance.
\end{abstract}

KEY WORDS carbohydrat and fat intake, triglyceride, body fat, BMI, cardiorespiratory endurance

\section{PENDAHULUAN}

Tujuan seseorang melakukan olahraga selain untuk menjaga supaya tubuh tetap sehat, juga untuk menyalurkan hobi dan meraih prestasi. Ditinjau dari segi kesehatan, olahraga dapat meningkatkan daya tahan tubuh dan menjaga seseorang dari serangan beberapa penyakit tertentu. Di samping itu, olahraga dapat juga membantu penyembuhan penyakit, seperti: jantung koroner, diabetes mellitus, hipertensi, dan obesitas (1).

Olahraga sepak bola merupakan salah satu gerakan tubuh yang memerlukan banyak energi untuk mencapai daya tahan jantung paru yang maksimal. Salah satu indikator seseorang mempunyai daya tahan jantung paru yang baik adalah mempunyai tingkat kebugaran yang sempurna dan baik (2).

Aktivitas olahraga membutuhkan metabolisme optimal dari makronutrien, seperti: karbohidrat, lemak, dan protein. Metabolisme optimal makronutrien tergantung dari adanya ketersediaan makronutrien. Jika kebutuhan makronutrien tercukupi, atlet dapat tampil maksimal dalam setiap aktivitas olahraga. Penguraian sempurna zat-zat gizi tersebut menghasilkan nilai energi tertentu, 1 gram karbohidrat menghasilkan $4 \mathrm{kkal}$ energi dan 1 gram lemak menghasilkan $9 \mathrm{kkal}$ energi. Menu atlet harus disusun berdasarkan jumlah kebutuhan dan komposisi gizi penghasil energi yang seimbang. Menu makanan harus mengandung karbohidrat sebanyak $60-70 \%$ dan lemak $20-25 \%$ dari total kebutuhan energi seorang atlet $(3,4)$.

Sehubungan dengan belum diketahuinya kontribusi zat gizi karbohidrat dan lemak serta faktor-faktor lainnya seperti indeks massa tubuh (IMT), kadar trigliserida, dan persentase lemak tubuh (PLT) terhadap daya tahan jantung paru sepak bola, maka perlu dilakukan penelitian yang bersifat cross sectional dengan sasaran atlet sepak bola Divisi Utama PSSI Liga Bank Mandiri tahun 2003. Penelitian ini diharapkan dapat dijadikan sebagai salah satu alternatif untuk memprediksi faktor-faktor yang mempengaruhi peningkatan daya tahan jantung paru atlet sepak bola.

Berdasarkan latar belakang di atas, maka tujuan penelitian ini adalah untuk mengetahui hubungan antara pola konsumsi karbohidrat dan pola konsumsi lemak dengan daya tahan jantung paru pada atlet sepak bola.

\footnotetext{
1 Jurusan Gizi Poltekkes Nanggroe Aceh Darussalam, JI. Dr. T. Syarief Thayeb, Lampriet Banda Aceh, NAD, e-mail: ferryfe@yahoo.co.id 2 Fakultas IImu Keolahragaan, JI. Kolombo Baru, Yogyakarta, e-mail: kushartanti_58@yahoo.co.id
} 


\section{BAHAN DAN METODE}

Penelitian ini merupakan penelitian noneksperimental dengan menggunakan rancangan cross sectional yang dilakukan pada saat libur setengah kompetisi Divisi Utama PSSI Liga Bank Mandiri IX tahun 2003 selama 20 hari, yaitu mulai tanggal 21 April sampai dengan 8 Mei 2003.

Variabel pada penelitian ini meliputi: variabel independen (pola konsumsi karbohidrat dan pola konsumsi lemak), variabel antara (IMT, kadar trigliserida darah, dan PLT), serta variabel dependen (daya tahan jantung paru) atlet sepak bola PS Semen Padang. Antarvariabel tersebut diamati dan diukur pada waktu yang bersamaan.

Penelitian dilaksanakan pada klub sepak bola PS Semen Padang Divisi Utama PSSI Liga Bank Mandiri IX tahun 2003, dengan subjek penelitian adalah seluruh atlet sepak bola PS Semen Padang yang bersedia dijadikan subjek penelitian. Pengumpulan data primer yang terdiri dari daya tahan jantung paru dikumpulkan menggunakan metode prediksi multitahap, pola konsumsi karbohidrat dan lemak dikumpulkan menggunakan metode food recall selama 2x24 jam yang selanjutnya diolah menggunakan program komputer. Data PLT diukur menggunakan skinfold caliper, data kadar trigliserida menggunakan metode CHAD PAP, dan indeks IMT diukur dengan cara mengukur berat badan dibagi kuadrat tinggi badan.

Analisis data dilakukan secara univariat, bivariat, dan multivariat dengan uji kai-kuadrat, sedangkan regresi linear dan regresi logistik menggunakan program komputer.

\section{HASIL DAN BAHASAN}

\section{Karakteristik responden}

Hasil pengumpulan data karakteristik atlet sepak bola PS Semen Padang Divisi Utama PSSI Liga Bank Mandiri tahun 2003 meliputi: umur, status perkawinan, pendidikan, dan asal atlet sepak bola PS Semen Padang (Tabel 1).

\section{Gambaran daya tahan jantung paru}

Hasil pengukuran daya tahan jantung paru atlet sepak bola PS Semen Padang didapatkan rata-rata daya tahan jantung paru sebesar $52,452 \mathrm{~mL} / \mathrm{kg} \mathrm{BB} /$ menit $\pm 7,493 \mathrm{~mL} / \mathrm{kg}$ $\mathrm{BB} /$ menit dengan rentang $40,5 \mathrm{~mL} / \mathrm{kg} \mathrm{BB} / \mathrm{menit}$ sampai dengan $64 \mathrm{~mL} / \mathrm{kg} \mathrm{BB} /$ menit. Hasil ini telah memenuhi persyaratan standar daya tahan jantung paru untuk olahraga sepak bola berdasarkan keputusan yang ditetapkan oleh Perhimpunan Pembina Kesehatan Olahraga Indonesia (PPKORI) sebesar 50-57 mL/kg BB/menit (5). Hasil penelitian ini juga tidak berbeda jauh dengan penelitian Harling dkk. (6) yang menemukan bahwa rata-rata $\mathrm{VO}_{2}$ maks responden penelitiannya sebesar $51,1 \pm 5,8 \mathrm{~mL} / \mathrm{kg} \mathrm{BB} /$ menit. Penelitian
TABEL 1. Distribusi karakteristik atlet sepak bola PS Semen Padang tahun 2003

\begin{tabular}{lcc}
\hline \multicolumn{1}{c}{ Variabel } & $\mathbf{n}$ & $\mathbf{\%}$ \\
\hline Umur & 6 & 26,1 \\
$20-24$ & 13 & 56,5 \\
$25-29$ & 4 & 17,4 \\
$30-34$ & & \\
Status perkawinan & 11 & 47,8 \\
$\quad$ Kawin & 12 & 52,2 \\
$\quad$ Tidak kawin & & \\
Pendidikan & 21 & 91,3 \\
SLTA & 2 & 8,7 \\
Perguruan tinggi & & \\
Asal & 4 & 17,4 \\
Padang & 4 & 17,4 \\
Medan & 4 & 17,4 \\
Aceh & 1 & 4,3 \\
Lampung & 1 & 4,3 \\
Bengkulu & 4 & 17,4 \\
Jawa & 1 & 4,3 \\
Ambon & 1 & 4,3 \\
Papua & 1 & 4,3 \\
Brazil (pemain asing) & 1 & 4,3 \\
Chili (pemain asing) & 1 & 4,3 \\
Gueina (pemain asing) & & \\
Kebiasaan merokok & 7 & 30,4 \\
Merokok & 16 & 69,6 \\
$\quad$ Tidak merokok & & \\
&
\end{tabular}

Williford dkk. (7) juga melaporkan bahwa rata-rata $\mathrm{VO}_{2}$ maks tim sepak bola sekolah tinggi olahraga di Amerika sebesar $51,5 \pm 6,8 \mathrm{~mL} / \mathrm{kg} \mathrm{BB} / \mathrm{menit}$ walaupun menggunakan tes performance ( $\mathrm{VO}_{2}$ maks) dengan treadmill test. Penelitian pada pemain sepak bola profesional di Singapura juga diperoleh hasil $\mathrm{VO}_{2}$ maks yang lebih tinggi yaitu sebesar $58,2 \pm 3,7 \mathrm{~mL} /$ $\mathrm{kg} \mathrm{BB} /$ menit (8). Perbedaan ini disebabkan pola latihan serta umur pemain sepak bola profesional di Singapura $(23,6 \pm 4,9)$ berbeda dengan umur atlet PS Semen Padang $(26,65 \pm 3,02)$. Namun demikian, penelitian Agustini dan Mas'ud (9) juga menemukan nilai $\mathrm{VO}_{2}$ maks kelompok olahragawan sepak bola yang lebih tinggi yaitu sebesar $60,79 \pm 11,37 \mathrm{~mL} / \mathrm{kg} \mathrm{BB} /$ menit. Hal ini disebabkan adanya perbedaan metode pengujian $\mathrm{VO}_{2}$ maks, yaitu menggunakan step up test.

Berdasarkan pengelompokan daya tahan jantung paru yang ditetapkan oleh PERKONI, dapat diketahui bahwa sebanyak $60,9 \%$ atlet sepak bola responden penelitian ini termasuk kategori baik dan sisanya sebanyak $39,1 \%$ atlet sepak bola termasuk kategori kurang.

\section{Gambaran pola konsumsi karbohidrat}

Hasil pengumpulan data pola konsumsi karbohidrat didapatkan rata-rata tingkat konsumsi karbohidrat atlet sebanyak $650,13 \mathrm{~g} \pm 71,49 \mathrm{~g}$ dengan rentang antara $473 \mathrm{~g}-$ $780 \mathrm{~g}$. Tingkat konsumsi karbohidrat atlet yang memenuhi $60-70 \%$ dari total karbohidrat sebanyak $82,6 \%$ dan yang tingkat konsumsi karbohidratnya rendah sebanyak $17,4 \%$. 
TABEL 2. Hubungan pola konsumsi karbohidrat dan lemak dengan daya tahan jantung paru atlet sepak bola PS Semen Padang tahun 2003

\begin{tabular}{|c|c|c|c|c|c|c|c|c|c|}
\hline \multirow{3}{*}{ Kategori } & \multicolumn{4}{|c|}{ Daya tahan jantung paru } & \multirow{2}{*}{\multicolumn{2}{|c|}{ Total }} & \multirow{3}{*}{$\mathbf{p}$} & \multirow{3}{*}{ OR } & \multirow{3}{*}{ IK $95 \%$} \\
\hline & \multicolumn{2}{|c|}{ Baik } & \multicolumn{2}{|c|}{ Kurang } & & & & & \\
\hline & $\mathbf{n}$ & $\%$ & $\mathbf{n}$ & $\%$ & $\mathbf{n}$ & $\%$ & & & \\
\hline \multicolumn{10}{|l|}{ Karbohidrat } \\
\hline Normal & 13 & 68,4 & 6 & 31,6 & 19 & 100 & 0,751 & 6,5 & $0,555-76,175$ \\
\hline Rendah & 1 & 25,0 & 3 & 75,0 & 4 & 100 & & & \\
\hline Total & 14 & 60,9 & 9 & 39,1 & 23 & 100 & & & \\
\hline \multicolumn{10}{|l|}{ Lemak } \\
\hline Normal & 10 & 71,4 & 4 & 28,6 & 14 & 100 & 0,297 & 3,125 & $0,541-18,038$ \\
\hline Lebih & 4 & 44,4 & 5 & 55,6 & 9 & 100 & & & \\
\hline Total & 14 & 60,9 & 9 & 39,1 & 23 & 100 & & & \\
\hline
\end{tabular}

\section{Gambaran pola konsumsi lemak}

Hasil pengumpulan data pola konsumsi lemak didapatkan rata-rata tingkat konsumsi lemak atlet sebanyak $113,024 \mathrm{~g}+21,574 \mathrm{~g}$ dengan rentang antara 87,5-152 g. Tingkat konsumsi lemak atlet yang memenuhi kebutuhan 20 sampai dengan $25 \%$ dari total lemak sebanyak $60,9 \%$, dan yang tingkat konsumsi lemaknya tinggi sebanyak 39,1\%.

\section{Hubungan konsumsi karbohidrat dengan daya tahan jantung paru}

Di antara atlet sepak bola PS Semen Padang yang mengkonsumsi karbohidrat normal, sebanyak $68,4 \%$ mempunyai daya tahan jantung baik, sedangkan yang mengkonsumsi karbohidrat rendah hanya $25,0 \%$ yang mempunyai daya tahan jantung baik. Bagi atlet yang mengkonsumsi karbohidrat rendah, sebanyak 75,0\% mempunyai daya tahan jantung paru rendah, sedangkan yang mengkonsumsi karbohidrat normal hanya $31,6 \%$ yang mempunyai daya tahan jantung paru kurang (Tabel 2).

Hasil analisis uji statistik regresi linear dan kai-kuadrat pada tingkat kepercayaan $95 \%$ diketahui hubungan antara tingkat konsumsi karbohidrat dengan daya tahan jantung paru berpola positif $(r=0,070)$ dan hubungannya tidak bermakna $(p=0,751)$. Atlet yang mengkonsumsi karbohidrat dalam jumlah normal memiliki daya tahan jantung paru 6,5 kali lebih baik dibanding dengan atlet yang mengkonsumsi karbohidrat rendah (IK 95\%:0,555-76,175). Tidak adanya hubungan langsung antara karbohidrat dengan daya tahan jantung paru bukan berarti karbohidrat sama sekali tidak mempengaruhi daya tahan jantung paru.

Dari hasil analisis terhadap variabel antara IMT, PLT, dan kadar trigliserida darah pada penelitian ini, ternyata karbohidrat terlebih dahulu mempengaruhi IMT dan PLT secara langsung, selanjutnya IMT dan PLT akan mempengaruhi daya tahan jantung paru secara langsung. Menurut Sherman (10), pada kondisi setelah makan, konsentrasi gula darah yang digunakan untuk aktivitas adalah fungsi dari jumlah pelepasan glikogen dalam otot yang dilepaskan dari glukosa dalam hati. Selama aktivitas yang dilakukan tetap, konsentrasi kadar gula darah tetap pada tingkat $5 \mathrm{mmol} / \mathrm{L}$ sampai sekitar 2 jam aktivitas. Pada pengujian yang dilakukan, aktivitas yang dilakukan merupakan aktivitas yang bersifat ketahanan yang sumber energi utamanya adalah karbohidrat (glukosa). Selain itu, penelitian ini hanya bersifat cross sectional yang tidak berlangsung lama, sehingga berbagai aktivitas yang tidak stabil dapat berjalan cepat atau lambat dan dapat pula secara aerob atau anaerob yang kemungkinan penggunaan energinya berasal dari berbagai sumber sesuai dengan aktivitas yang dilakukan, termasuk glukosa darah.

\section{Hubungan pola konsumsi lemak dengan daya tahan jantung paru}

Diperoleh sebanyak $71,4 \%$ atlet yang mempunyai daya tahan jantung paru baik dan hanya $28,6 \%$ yang mempunyai daya tahan jantung paru kurang di antara atlet sepak bola PS Semen Padang yang mengkonsumsi lemak normal. Sedangkan di antara atlet yang mengkonsumsi lemak lebih, sebagian besarnya yaitu $55,6 \%$ mempunyai daya tahan jantung kurang dan hanya $44,4 \%$ yang mempunyai daya tahan jantung baik (Tabel 2).

Hasil analisis statistik regresi dan kai-kuadrat menggunakan tingkat kepercayaan 95\% tidak didapatkan hubungan yang bermakna antara tingkat konsumsi lemak dengan daya tahan jantung paru $(p=0,297)$ dan hubungan tersebut berpola negatif. Bagi atlet yang mengkonsumsi lemak lebih akan mempunyai peluang daya tahan jantung 3,125 kali lebih buruk dibandingkan dengan atlet yang mengkonsumsi lemak normal (IK 95: 0,541-18,038). Pada penelitian ini tidak ada hubungan langsung antara lemak dengan daya tahan jantung paru karena konsumsi lemak terlebih dahulu akan mempengaruhi kadar trigliserida darah, selanjutnya kadar trigliserida darah inilah yang langsung mempengaruhi daya tahan jantung paru atlet sepak bola PS Semen Padang. 


\section{Analisis multivariat}

Analisis multivariat menggunakan uji regresi logistik berganda dilakukan untuk mengetahui variabel yang paling berhubungan dengan daya tahan jantung paru antara variabel independen (pola konsumsi karbohidrat dan pola konsumsi lemak) dan variabel antara (PLT, kadar trigliserida darah, IMT) dengan variabel dependen (daya tahan jantung paru). Hasil analisis didapatkan variabel PLT merupakan variabel yang paling berpengaruh terhadap daya tahan jantung paru jika dibandingkan dengan variabel yang lain $(\mathrm{OR}=12)$.

Meningkatnya PLT dapat mengganggu kebebasan seseorang untuk bergerak atau melakukan aktivitas fisik. Penurunan aktivitas fisik ini dapat menurunkan kinerja sistem jantung, paru-paru, fungsi pembuluh darah, dan daya tahan kardiovaskuler yang merupakan gambaran daya tahan jantung paru. Hasil penelitian ini senada dengan penelitian Sulistyowati (11) pada kelompok binaan Puskesmas DKI Jakarta yang menunjukkan rata-rata $\mathrm{VO}_{2}$ maks menurun dengan meningkatnya PLT. PLT yang tinggi pada sebagian besar atlet disebabkan konsumsi lemak atau karbohidrat yang tinggi serta kurangnya pengaturan makan yang adekuat, sehingga terjadi penumpukan kadar trigliserida yang selanjutnya menyebabkan terjadinya penumpukan lemak dalam tubuh. Penumpukan lemak ini yang pada akhirnya menyebabkan penurunan daya tahan jantung paru atlet dalam melakukan kegiatan sepak bola.

Setelah dilakukan analisis menggunakan korelasi parsial dengan mengkontrol kebiasaan merokok dan umur atlet, diketahui bahwa $25 \%$ daya tahan jantung paru dipengaruhi oleh PLT, sedangkan sisanya sebanyak $75 \%$ dipengaruhi oleh variabel konfonding seperti: intensitas, lama, dan frekuensi latihan. Diasumsikan juga bahwa daya tahan jantung paru juga dipengaruhi oleh variabel lain yang tidak tercantum dalam kerangka konsep penelitian ini seperti: pola konsumsi zat gizi mikro, faktor psikologis, lingkungan herediter, dan masih banyak lagi penyebab lainnya.

Jika hanya umur saja yang dikontrol, maka besarnya pengaruh PLT terhadap daya tahan jantung paru meningkat menjadi $30 \%$ dengan hubungan yang signifikan $(p=0,009)$. Dari hasil tersebut diketahui bahwa umur juga berpengaruh terhadap daya tahan jantung atlet sepak bola pada penelitian ini. Hal ini sesuai dengan penelitian Permaesih dkk. (12) pada kelompok tertentu yang mendapatkan hubungan negatif antara umur dengan $\mathrm{VO}_{2}$ maks $(p=0,0001)$.

Jika variabel rokok saja yang dikontrol, maka besarnya pengaruh PLT terhadap daya tahan jantung paru sebesar $26 \%$ dengan hubungan yang signifikan $(p=0,015)$. Dengan demikian, merokok juga merupakan salah satu faktor yang mempengaruhi daya tahan jantung paru. Penelitian ini sesuai dengan yang dikemukakan oleh Sadoso (13) bahwa rokok sangat besar pengaruhnya terhadap daya tahan jantung paru karena pada satu batang rokok terkandung 3$6 \%$ karbonmonoksida (CO). Afinitas (daya tarik-menarik) karbonmonoksida pada hemoglobin adalah 200-300 kali lebih kuat dibanding oksigen, sehingga pengangkutan oksigen ke seluruh tubuh terhambat dan menyebabkan daya tahan jantung paru atlet juga menurun. Kurang bermaknanya pengaruh rokok jika dibandingkan dengan PLT karena di samping merokok, para atlet sepak bola PS Semen Padang selalu melakukan latihan rutin untuk meningkatkan kebugaran (daya tahan jantung paru), sehingga diasumsikan bahwa pengaruh rokok terhadap penurunan daya tahan jantung paru atlet tersebut berkurang.

\section{KESIMPULAN DAN SARAN}

\section{Kesimpulan}

Pada penelitian ini tidak ada hubungan antara pola konsumsi karbohidrat dan lemak dengan daya tahan jantung paru atlet sepak bola PS Semen Padang. Selain itu, didapatkan pula bahwa PLT merupakan variabel yang paling dominan mempengaruhi daya tahan jantung paru atlet sepak bola PS Semen Padang, jika dibandingkan dengan tingkat konsumsi karbohidrat, tingkat konsumsi lemak, IMT, dan kadar trigliserida darah.

\section{Saran}

Pelatih dan asisten pelatih klub sepak bola PS Semen Padang diharapkan dapat menurunkan pola konsumsi lemak atlet dan mempertahankan tingkat konsumsi karbohidarat. Dalam penjaringan atlet sepak bola profesional juga perlu diperhatikan IMT, PLT, kadar trigliserida darah, dan daya tahan jantung paru atlet.

Penelitian dengan rancangan yang berbeda dan meneliti variabel lain terutama intensitas latihan juga perlu diteliti lebih lanjut.

\section{Ucapan terima kasih}

Peneliti mengucapkan terima kasih kepada Gubernur Provinsi Nanggroe Aceh Darussalam, Direktur Poltekkes Banda Aceh, para atlet, dan pengurus sepak bola PS Semen Padang, serta semua pihak yang tidak dapat disebutkan satu per satu. 


\section{RUJUKAN}

1. Lamb DR. Evaluation of Cardiovascular Function and Aerobic Endurance Performance Physiology of Exercise. New York: Mc Milan Publishing Company; 1984.p.137-71.

2. Sumosardjuno S. Petunjuk Praktis Kesehatan Olahraga. 1st ed. Jakarta: PT Pustaka Karya Grafika Utama; 1987.

3. Ranggasudira AR. Gizi dan Olahraga. Jakarta: Balai Penerbit FKUI; 1984. p. 51.

4. Irianto DP. Makanan Olahragwan dalam Menghadapi Tantangan. Olahraga 1998; 2: 75-9.

5. Kosasih E. Olahraga Teknik dan Program Latihan. Edisi Revisi. Jakarta: Akademika Pressindo; 1993.

6. Harling SA, Tong RJ, and Micleborough TD. The Oxygen Uptake Response Running Exhaustion at Peak Treadmill Speed. Med Sci Sports Exerc 2003;4:663-7.

7. Williford HN, Kirkpatrick J, Olson MS, Blessing DL, Wang NZ. Physical and Performance Characteristics of Successful High School Football Players. Am J Sports Med 1994;22(6):859-62.
8. Aziz AR. The Relationship between Maximal Oxygen Uptake and Repeated Sprint Performance Indices in Field Hockey and Soccer Players. The Journal of Sport Medicine and Physical Fitness 2000;40:195-200.

9. Agustini NI, Mas'ud I. Gambaran Status Gizi dan VO2 Max Kelompok Olahragawan dan Kelompok Mahasiswa Kedokteran. Medika 1989;15(1):30-4.

10. Sherman, William M. Metabolism of Sugar and Physical Performance. Am J Clin Nutr 1995; 62: 228s-41s.

11. Sulistyowati E. Faktor-Faktor yang Berhubungan dengan VO2 Maks Orang Usia Lanjut Binaan Puskesmas DKI Jakarta Tahun 1998 [tesis]. Jakarta: Universitas Indonesia; 2000.

12. Permaesih D, Kusdinar A, MI Ivone, M Dangsina R, Hendro. Faktor-Faktor yang Mempengaruhi Ketahanan Kardiovaskuler pada Pria Dewasa Kelompok Khusus. Buletin Penelitian Kesehatan 1999:27(2);30-45.

13. Sadoso. Rokok: Risiko Janin dan Impotensi. Intisari [serial online] 2001 Sept [cited 2002 Jun 5]. Available from: www.indomedia.com. 